Portland State University

PDXScholar

\title{
Travel to Food: Transportation Barriers for the Food Insecure in Tampa Bay
}

\author{
Kevin Salzer \\ University of South Florida \\ Ann Joslin \\ University of South Florida
}

Follow this and additional works at: https://pdxscholar.library.pdx.edu/trec_reports

Part of the Food Studies Commons, Transportation Commons, and the Urban Studies Commons Let us know how access to this document benefits you.

\section{Recommended Citation}

Salzer, Kevin and Ann Joslin. Travel to Food: Transportation Barriers for the Food Insecure in Tampa Bay. NITC-SS-997. Portland, OR. Transportation Research and Education Center (TREC) 2017. https://doi.org/ 10.15760/trec.182

This Report is brought to you for free and open access. It has been accepted for inclusion in TREC Final Reports by an authorized administrator of PDXScholar. Please contact us if we can make this document more accessible: pdxscholar@pdx.edu. 


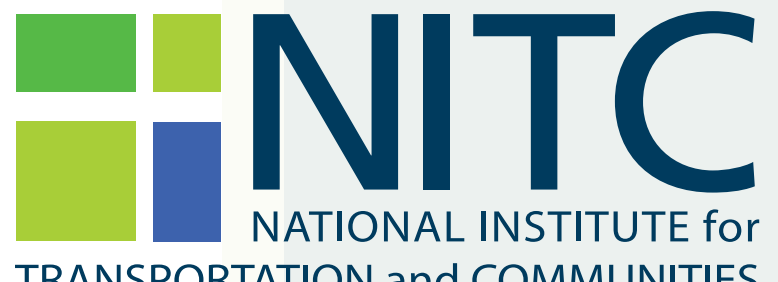

TRANSPORTATION and COMMUNITIES

FINAL REPORT

Travel to Food: Transportation Barriers for the Food Insecure in Tampa Bay

NITC-SS-997 - September 2017

NITC is a U.S. Department of Transportation

national university transportation center.

HI! TREC 



\title{
TRAVEL TO FOOD: \\ TRANSPORTATION BARRIERS FOR THE FOOD INSECURE IN TAMPA BAY
}

\section{Final Report}

NITC-SS-997

by

\author{
Kevin Salzer \\ \& Ann Joslin \\ University of South Florida
}

for

National Institute for Transportation and Communities (NITC)

P.O. Box 751

Portland, OR 97207

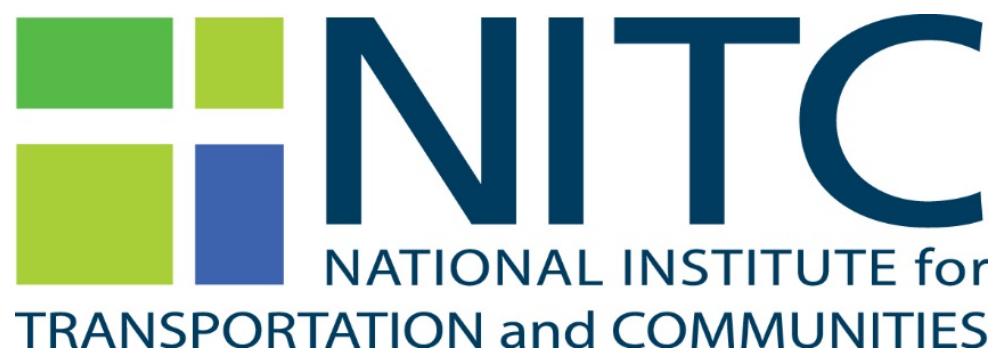

September 2017 



\begin{tabular}{|c|c|c|c|c|}
\hline \multicolumn{5}{|c|}{ Technical Report Documentation Page } \\
\hline $\begin{array}{l}\text { 1. Report No. } \\
\text { NITC-SS-997 }\end{array}$ & \multicolumn{2}{|l|}{ 2. Government Accession No. } & \multicolumn{2}{|c|}{ 3. Recipient's Catalog No. } \\
\hline \multirow{2}{*}{\multicolumn{3}{|c|}{$\begin{array}{l}\text { 4. Title and Subtitle } \\
\text { Travel to Food: Transportation Barriers for the Food Insecure in Tampa Bay }\end{array}$}} & \multicolumn{2}{|c|}{$\begin{array}{l}\text { 5. Report Date } \\
\text { September, } 2017\end{array}$} \\
\hline & & & \multicolumn{2}{|c|}{ 6. Performing Organization Code } \\
\hline \multicolumn{3}{|l|}{$\begin{array}{l}\text { 7. Author(s) } \\
\text { Kevin Salzer \& Ann Joslin }\end{array}$} & \multicolumn{2}{|c|}{ 8. Performing Organization Report No. } \\
\hline \multirow{2}{*}{\multicolumn{3}{|c|}{$\begin{array}{l}\text { 9. Performing Organization Name and Address } \\
\text { University of South Florida } \\
4202 \text { E. Fowler Ave. CUT100 } \\
\text { Tampa, FL } 33620\end{array}$}} & \multicolumn{2}{|c|}{ 10. Work Unit No. (TRAIS) } \\
\hline & & & \multicolumn{2}{|c|}{$\begin{array}{l}\text { 11. Contract or Grant No. } \\
01-13\end{array}$} \\
\hline \multirow{2}{*}{\multicolumn{3}{|c|}{$\begin{array}{l}\text { 12. Sponsoring Agency Name and Address } \\
\text { National Institute for Transportation and Communities (NITC) } \\
\text { P.O. Box } 751 \\
\text { Portland, OR } 97207\end{array}$}} & \multirow{2}{*}{\multicolumn{2}{|c|}{$\begin{array}{l}\text { 13. Type of Report and Period Covered } \\
\text { Final Report } \\
\text { 14. Sponsoring Agency Code }\end{array}$}} \\
\hline & & & & \\
\hline \multicolumn{5}{|c|}{ 15. Supplementary Notes } \\
\hline \multicolumn{5}{|c|}{$\begin{array}{l}\text { 16. Abstract } \\
\text { In partnership with the Center for Urban Transportation Research (CUTR) at the University of South Florida (USF), the Transportation } \\
\text { Innovation Group informed practical transportation solutions aimed at improved food access in Tampa Bay (Hillsborough, Pinellas and Pasco } \\
\text { counties). The food pantry/bank sites that are part of Tampa Bay Network to End Hunger (TBNTEH) helped to gather data through a survey } \\
\text { and interviews of food-related organizational leadership, staff and volunteers from each site to gain insight into how clients currently access } \\
\text { emergency food sites (qualitative). This information was supplemented with a GIS analysis of transit accessibility for the food insecure in } \\
\text { Tampa Bay (quantitative). }\end{array}$} \\
\hline \multicolumn{5}{|c|}{$\begin{array}{l}\text { Funding for this project was provided, in part, by the National Institute for Transportation and Communities (NITC) at Portland State } \\
\text { University. This project entitled “Travel to Food: Transportation Barriers for the Food Insecure in Tampa Bay” fits with the NITC's theme of } \\
\text { safe, healthy and sustainable transportation choices to foster livable communities in the following ways: } \\
\text { Identify gaps in the transportation system for vulnerable communities; } \\
\text { - Lead to focused solutions to improve access to healthy food; } \\
\text { Lead to added sustainable transportation options; and } \\
\text { Access to food is an essential precursor to livability. } \\
\text { Background: The dominance of the automobile in the southeast has impacted the urban and suburban built environment, resulting in barriers to } \\
\text { transportation access. The vulnerability of the food insecure makes them an indicator population of the larger transportation system; mobility } \\
\text { and housing location options are limited for this population. The grocery industry's trend toward larger stores and higher-value inventory to } \\
\text { maximize shelf space value has left lower-income neighborhoods with fewer food retail options. The lack of food access is experienced more } \\
\text { acutely in lower-income neighborhoods where auto ownership is lower and dependence on alternative modes of transportation (e.g., transit, bike } \\
\text { and walking) is higher. }\end{array}$} \\
\hline \multicolumn{2}{|c|}{$\begin{array}{l}\text { 17. Key Words } \\
\text { Food Insecure, Food Access, and Transit Access }\end{array}$} & \multicolumn{3}{|c|}{$\begin{array}{l}\text { 18. Distribution Statement } \\
\text { No restrictions. Copies available from NITC: } \\
\text { www.nitc-utc.net }\end{array}$} \\
\hline 19. Security Classification (of this report) & $\begin{array}{l}\text { 20. Security Classification (of } \\
\text { Unclassified }\end{array}$ & page) & $\begin{array}{l}\text { 21. No. of Pages } \\
34\end{array}$ & 22. Price \\
\hline
\end{tabular}




\section{ACKNOWLEDGEMENTS}

This project entitled "Travel to Food: Transportation Barriers for the Food Insecure in Tampa Bay" was funded by the National Institute for Transportation and Communities (NITC) at Portland State University.

This project could not have been completed without the support and participation of the community stakeholders and members of the Tampa Bay Network to End Hunger (TBNTEH). A special thank you goes to the TBNTEH Transportation Work Group for providing insight and its work on developing the food access survey.

We express our gratitude to the TBNTEH staff, especially Caitlyn Peacock and Ace Padin, who helped coordinate meetings and helped gather data for this analysis. A special thanks to Pat Rogers, past chair of the TBNTEH. Her leadership created the framework for this collaborative research.

\section{DISCLAIMER}

The contents of this report reflect the views of the authors, who are solely responsible for the facts and the accuracy of the material and information presented herein. This document is disseminated under the sponsorship of the U.S. Department of Transportation University Transportation Centers Program in the interest of information exchange. The U.S. Government assumes no liability for the contents or use thereof. The contents do not necessarily reflect the official views of the U.S. Government. This report does not constitute a standard, specification, or regulation.

\section{RECOMMENDED CITATION}

Salzer, Kevin and Ann Joslin. Travel to Food: Transportation Barriers for the Food Insecure in Tampa Bay. NITC-SS-997. Portland, OR. Transportation Research and Education Center (TREC) 2017. 


\section{TABLE OF CONTENTS}

EXECUTIVE SUMMARY ................................................................................................... 1

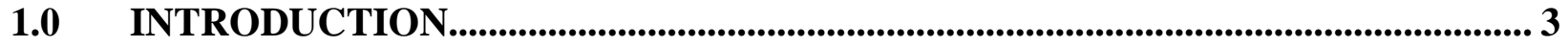

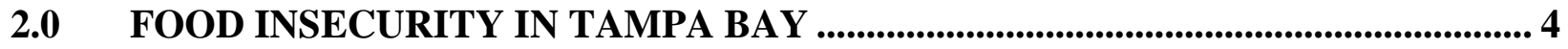

3.0 IMPACT OF TRANSPORTATION ON TAMPA BAY'S FOOD INSECURE ......... 5

4.0 RESULTS OF COMMUNITY STAKEHOLDER SURVEY .................................. 6

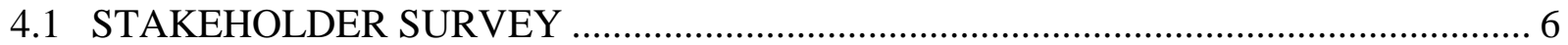

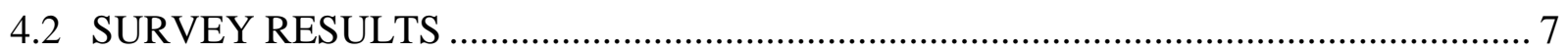

4.2.1 Survey Questions Regarding Respondent Characteristics ................................... 7

4.2.2 Survey Questions Regarding Client Transportation Experiences.............................. 9

5.0 RESULTS OF FOOD ACCESS SPATIAL ANALYSIS............................................. 12

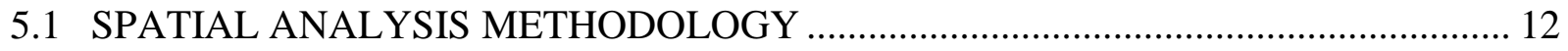

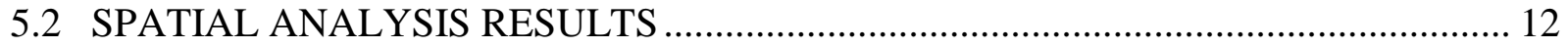

6.0 RECOMMENDATIONS AND CONCLUSIONS................................................ 15

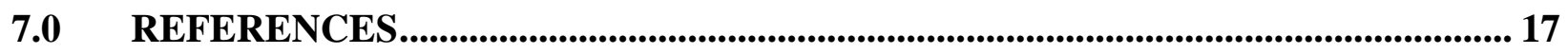

\section{APPENDIX}

COMMUNITY STAKEHOLDER SURVEY FORM

\section{LIST OF TABLES}

Table 4.1. Positions Held by Survey Respondents .............................................................. 7

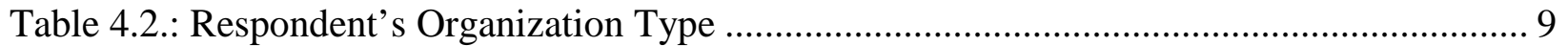

Table 4.3. Priority Modes of Transportation ........................................................................... 9

Table 4.4: Distance of Organization from Bus Stop................................................................. 10

Table 4.5: Frequency of Client Complaints about Lack of Transportation ................................ 10

Table 4.6: Frequency of Clients Visiting Food Pantries or Meal Providers ............................... 11

Table 5.1: 2014 Transit Access and Food Insecure in Tampa Bay ........................................... 13

\section{LIST OF FIGURES}

Figure 5.1: Local Transit Routes and Three-quarter-mile Buffer Area .................................... 13 



\section{EXECUTIVE SUMMARY}

Food insecurity affects a wide range of people and most acutely affects vulnerable populations such as children, pregnant women, seniors and individuals with disabilities. It also greatly impacts at-risk populations, including people whose income does not qualify them for federal food assistance programs.

In the Tampa Bay region, many of the most effective organizations that address food insecurity are part of a non-profit network (501c3) called the Tampa Bay Network to End Hunger (TBNTEH). The TBNTEH's mission is to end hunger by bringing people together to find solutions that eliminate barriers, increase access and expand the amount of nutritious food available. Targeted TBNTEH populations include veterans, seniors, youth and disadvantaged populations.

In three Tampa Bay counties (Hillsborough, Pasco and Pinellas), 16\% of residents are estimated to be food insecure (Feeding America, 2014). This is above the average of $14.3 \%$ for counties nationwide.

Because transportation access plays a key role in the TBNTEH's mission, it created the Transportation Innovation Group (TIG) in 2011 to explore the linkages between transportation access issues and food insecurity. Kevin Salzer, one of the researchers on this project, served as TIG's chair. In 2012, TIG presented its strategic plan at the TBNTEH Annual Meeting to address the following community issues of the food insecure that are transportation-related:

1. Food Deserts

2. Transit Access

3. Transportation Disadvantaged

4. Food Safety \& Transport

Because of Tampa Bay's sprawling land-use patterns, automobiles are the dominant transportation mode. The dominance of the automobile has impacted the urban and suburban built environment in the region. This means there are many features in the built environment oriented towards the automobile. These include large blocks, large arterials, neighborhoods with low connectivity (e.g., many cul de sacs), and large parking lots. These features become impediments to pedestrians and bicyclists. They also limit access to transit riders.

Receiving this NITC grant helped the TBNTEH TIG to work with multiple community stakeholders to address two of the four above strategic issues: transit access and transportation disadvantaged.

With TBNTEH and multiple community stakeholders who work with the food insecure in Tampa Bay, USF was able to collaborate on survey development and data gathering for the spatial analysis. The survey was designed to help identify transportation issues that affect the food insecure who use food pantries and meal providers. 
The survey revealed that public transit by bus was a common and important transportation mode to access food pantries and meal providers. However, nine of the 15 (60\%) food pantry/meal provider survey respondents reported that clients "frequently" complain of a lack of transportation.

The spatial analysis revealed that $31 \%$ of individuals who are food insecure in Hillsborough, Pinellas and Pasco counties do not have adequate access to transit.

Based upon the discussion of the survey and spatial analysis with TBNTEH and community partners, recommendations for next steps to address transportation issues experienced by the food insecure are the following:

1. Transit should be made more efficient and straight-forward for food pantry/meal provider clients. Emergency-food community stakeholders should partner with Hillsborough Area Regional Transit Authority (HART), Pinellas Suncoast Transit Authority (PSTA) and Pasco County Public Transportation (PCPT) to identify strategies to increase access to food pantry and meal provider sites and grocery stores. As part of this collaboration, organizations should ensure their clients are aware of services they may qualify for, such as paratransit or other services for the transportation-disadvantaged.

2. Community stakeholders should explore multiple low-cost, transportation-improvement strategies to bridge food access gaps. One potential strategy is leveraging vehicles owned by faith-based organizations and organizations that have missions that include serving the food insecure. A second strategy is bus-pass programs to distribute free or reduced-cost bus passes to clients. A third strategy is private partnerships with retail outlets. For example, grocery stores that stand to benefit from additional customers may schedule a free or affordable shuttle pickup to bring food insecure customers lacking transportation to their store.

\section{Establish an organizational infrastructure dedicated to transportation for the food insecure that is initially a network of TBNTEH, transit authorities, and the community stakeholders who filled out the survey. This network can lead to new relationships, funding and pilot projects to help the food insecure in Tampa Bay access food.}

This project fits with the NITC's theme of safe, healthy and sustainable transportation choices to foster livable communities in the following ways:

- Identify gaps in the transportation system for vulnerable communities;

- Lead to focused solutions to improve access to healthy food;

- Lead to added sustainable transportation options; and

- Access to food is an essential precursor to livability.

This project also supports the FTA's Ladders of Opportunity goals by helping to:

- Identify and quantify transportation access gaps for food-insecure populations.

- Facilitate information exchange between emergency food and transportation providers.

- Initiate development of scalable community, transportation-focused pilot projects to improve access to nutrition, healthcare and jobs. 


\subsection{INTRODUCTION}

In partnership with the Center for Urban Transportation Research (CUTR) at the University of South Florida (USF), the Tampa Bay Network to End Hunger Transportation Innovation Group (TBNTEH TIG) completed this much-needed project to inform practical transportation solutions aimed at improved food access in Tampa Bay (Hillsborough, Pinellas and Pasco counties).

Food insecurity is addressed in large part by food pantries and meal providers through a community's emergency food system. This system is often made up of faith-based organizations (FBOs) and other charitable groups that serve as food pantries or meal providers. According to Feeding America, a "food pantry functions as the arms that reach out to that community directly. Some utilize mobile food pantries, which reach people in areas of high need.” Meal providers offer prepared food on-site.

In the three counties served by this project, many of the organizations that make up Tampa Bay's emergency food system are part of the TBNTEH, and they are supported by Feeding America's network of food banks.

Feeding America helps to combat hunger through coordinated efforts by supporting food banks in all 50 states. In turn, the Feeding America-supported food banks partner with more than 46,000 FBOs and charitable groups. The FBOs and charitable groups operate more than 58,000 food programs, including nearly 19,000 programs that provide meals for on-site consumption, and more than 39,000 programs that provide groceries for use at home (Weinfield, 2014).

For this NITC project, the food pantry and meal provider organizations that are part of TBNTEH helped to gather data through a survey and interview of food-related organization leadership, staff and volunteers from each site (qualitative). Key transportation-focused questions were asked to gain insight into how clients currently access emergency food sites. The specific research questions this survey answered were:

- What modes of transportation do clients use to access emergency food sites?

- How often do clients voice concern about transportation?

- What mobility options do clients have?

- Are clients aware of the transit system?

This qualitative information was supplemented by CUTR with a spatial analysis of transit accessibility for the food insecure in Tampa Bay (quantitative). Much of the data for the spatial analysis were provided by TBNTEH/Feeding America.

The survey and spatial analysis identified transportation barriers and challenges to accessing emergency food in the Tampa Bay area so that limited transportation resources could be better focused on the food access problem at a community level.

This report presents the research findings and provides recommendations and next steps. 


\subsection{FOOD INSECURITY IN TAMPA BAY}

Many people in Tampa Bay are food insecure and lack access each month to enough food for an active, healthy lifestyle. According to Feeding America, 16\% of Tampa Bay residents are estimated to be food insecure. This is above the average of $14.3 \%$ for counties nationwide (Map the Meal Gap, 2015).

Food insecurity reflects a household's need to tradeoff between adequate food and other basic needs such as housing, healthcare or transportation. A person may skip a meal in order to pay for other expenses. In 2013, food-insecure individuals reported to have a shortfall in their food budgets of an average \$16.82 per person per week (Weinfield, 2014).

Food insecurity has been found to adversely affect individuals’ physical and mental health, particularly among those who are part of vulnerable populations such as pregnant women, new mothers, children and older adults. Food insecurity is generally associated with a range of chronic illnesses such as hypertension, hyperlipidemia and cardiovascular issues (Seligman et al., 2009). Food insecurity is also associated with the increased risk for hypoglycemia (Seligman et al., 2014). According to the Mayo Clinic, untreated hypoglycemia can lead to seizures, loss of consciousness and death.

Food insecure women are at risk for major depression and other mental health issues (Heflin et al., 2005; Whitaker et al., 2006). In children, several studies have demonstrated that food insecurity damages cognitive development and is associated with poor school performance (Gundersen et al., 2011).

Through the work of the emergency food system in Tama Bay, many food-insecure households are able to access food. However, food access is dependent on the ability to reach the food pick-up locations, which is why this project focuses on transportation needs of the food insecure. 


\subsection{IMPACT OF TRANSPORTATION ON TAMPA BAY'S FOOD INSECURE}

Given the sprawling and automobile-oriented nature of Tampa Bay, getting food from a food pantry or meal provider may require the use of a car. The cost of car ownership is unattainable for many food-insecure families and individuals, as limited income is associated with food insecurity (Weinfield, 2014).

The dominance of the automobile in Tampa Bay has impacted the urban and suburban built environment in the region. This means there are many features in the built environment that are oriented towards the automobile and not walking, biking or riding transit. These include large blocks, large arterials, neighborhoods with low connectivity (e.g., many cul de sacs), and large parking lots.

For example, imagine how transportation challenges affect a mother of three children attempting to carry groceries on foot to a bus stop, an elderly man carrying food several miles to his home, or a child on summer vacation attempting to cross a busy intersection to buy lunch. Adding to the transportation challenges presented in these examples, Florida's heat and an average of 105 rainy days per year in Tampa Bay make it difficult for non-motorists to access food year round.

For low-income individuals, mobility and housing location options are limited. This includes neighborhoods being located farther from grocery stores. The grocery industry's trend toward creating larger stores and higher-value inventory to maximize shelf space value has left lowerincome neighborhoods with fewer food retail options. In communities that have no or distant grocery stores (or otherwise lack healthy food options), there is an increased risk of premature death and chronic health conditions (Treuhaft, 2010). This situation may be exacerbated in lower-income neighborhoods where auto ownership is lower and dependence on alternative modes of transportation (e.g., transit, bike and walking) is higher. For this reason, inadequate transportation should be addressed to better meet the needs of food-insecure families. 


\subsection{RESULTS OF COMMUNITY STAKEHOLDER SURVEY}

\subsection{STAKEHOLDER SURVEY}

Food pantry and meal provider stakeholders in Hillsborough, Pasco and Pinellas counties met to develop the survey in conjunction with CUTR and the TBNTEH on April 19, 2016.

The final survey was presented to attendees at the 2016 TBNTEH annual conference in October. Additional food pantries and meal providers took the survey at the January 12, 2017, TBNTEH TIG meeting. Overall, 33 stakeholders from 25 organizations completed the survey process.

The eight-question survey can be found in the appendix.

Respondents came from the following organizations:

1. Neighborly Care Network

2. Metropolitan Ministries

3. Florida Institute for Community

4. Bay Care

5. Bay Care Behavioral

6. Exceptional

7. Hillsborough County Aging Services

8. Hacienda Villas

9. Youth and Family Alternatives

10. Pasco County Planning and Dev

11. Daystar Life Center

12. Department of Health (DOH) Women, Infants, and Children (WIC) Clinic

13. IASIS Healthcare/ Humane Medicaid Contractor

14. Whitwam Organics

15. TBNTEH

16. City of St. Petersburg 
17. Area Agency on Aging of Pasco-Pinellas

18. The Fresh Initiative Supply Hub

19. Florida Department of Health-Pinellas

20. University of South Florida

21. FDOH/ WIC \& Nutrition Division

22. Trinity Café

23. UF/IFAS Extension Family Nutrition Program

24. Seniors in Service

25. United Methodist Cooperative Ministries Suncoast

\subsection{SURVEY RESULTS}

\subsubsection{Survey Questions Regarding Respondent Characteristics}

Thirty-two of the 33 survey respondents shared their position at their organization (Table 4.1). Of the 32 food-insecure stakeholders who responded to the "Position" survey question, nine considered themselves executive leaders (28\%), four were students (12\%), and 19 (59\%) filled "Other" positions.

The 19 "Other" positions listed were: Grants Specialist, Masters-level Practitioner, Case Manager, Manager (2), Supervisor, Service Coordinator, Staff (2), Food Producer, Americorp/Vista Staff (3), Social Worker, Health and Wellness Coordinator, Nutrition Educator, Clinician, Employee Food Systems Developer, and a Director of Marketing \& Development.

Table 4.1: Positions Held by Survey Respondents

\begin{tabular}{l|r}
\hline Position & Count \\
\hline Executive Leader & 9 \\
\hline Student & 4 \\
\hline Other & 19 \\
\hline Total & $\mathbf{3 2}$ \\
\hline
\end{tabular}

Respondents were asked their organization's type (Food Pantry, Meal Provider, Transportationrelated, Other Food-related, Ministry, and Other). There were more than 33 answers because six respondents reported that their organizations fit in more than one organizational category (Table $4.2)$. 
Of the 33 respondents, the majority of organizations claimed that their organizational type was “Other” (16) followed by Meal Provider (9). Eighteen of the 33 respondents (55\%) considered their organization "food-related" (Food Pantry [4], Meal Provider [9], and Other Food-related [5]).

For the "Other” category (not “Other Food-related”), respondents listed the following organization types:

1. Support and emergency housing

2. After-school program

3. Outreach prevention

4. Therapeutic group home

5. HUD/Section 8

6. Community school

7. County food policy advisory council

8. DOH-WIC benefits

9. Medicaid insurance

10. Behavioral health/ community health outreach/ prevention

11. Local government

12. Gardening education

13. Council on aging

14. Provides bus passes and Wheels of Success program

15. Fresh produce supplier to pantries

16. Community health services 
Table 4.2: Respondent's Organization Type

\begin{tabular}{l|r}
\hline Organization Type & \multicolumn{1}{|c}{ Count } \\
\hline Food Pantry & 4 \\
\hline Meal Provider & 9 \\
\hline Transportation-related & 2 \\
\hline Other Food-related & 5 \\
\hline Ministry & 3 \\
\hline Other & 16 \\
\hline Total & $\mathbf{3 9}$ \\
\hline
\end{tabular}

\subsubsection{Survey Questions Regarding Client Transportation Experiences}

When asked about which transportation modes clients use the most (Table 4.3), 21 of 33 respondents who answered this question reported that their clients' top five modes to reach the respondents’ organizations are:

1. Family or Friend

2. Personal Automobile

3. Bus

4. Walk/Run

5. Bicycle

Ridesharing (Uber/Lyft) and taxis were less important transportation modes for their clients. Respondents were allowed to choose as many modes as they believed were priorities for their clients. Although Personal Automobile was a top mode, many clients are non-motorists or use inexpensive or free transportation modes for non-motorists.

Table 4.3. Priority Modes of Transportation

\begin{tabular}{l|r}
\hline Modes & \multicolumn{1}{|l}{ Count } \\
\hline Personal Automobile & 14 \\
\hline Family or Friend & 16 \\
\hline Bus & 15 \\
\hline Taxi & 6 \\
\hline Bicycle & 11 \\
\hline Walk/Run & 13 \\
\hline Rideshare (Uber/Lyft) & 3 \\
\hline Other & 1 \\
\hline Total Respondents & $\mathbf{2 1}$ \\
\hline
\end{tabular}


Seventeen of the 33 respondents reported on the distance of the respondents' organizations to the closest bus stops (Table 4.4). The survey shows that most organizations have a bus stop within three-quarters of a mile, suggesting that the organizations, for the most part, are accessible by transit. In the three-county service area, fixed-route bus service is the predominant mode of public transportation.

The survey did not capture if disabled clients are using paratransit service or if organizations are directing clients who are potentially eligible to paratransit services.

Table 4.4: Distance of Organization from Bus Stop

\begin{tabular}{l|r}
\hline How Far & \multicolumn{1}{|l}{ Count } \\
\hline Right in front & 6 \\
\hline Less than $1 / 4$ mile & 5 \\
\hline Less than $3 / 4$ of a mile & 4 \\
\hline Less than $1 \frac{1 / 2}{2}$ miles & 1 \\
\hline More than $1 \frac{1}{2}$ miles & 2 \\
\hline There isn’t a nearby bus stop & 1 \\
\hline Unsure & 2 \\
\hline Total Respondents & $\mathbf{1 7}$ \\
\hline
\end{tabular}

As shown in Table 4.5, 15 of the 33 respondents were food pantries or meal providers. These respondents shared how often they think their clients have issues with lack of transportation to food pantries or meal providers. Nine out of the 15 food pantry or meal provider respondents (60\%) reported that clients frequently complain about inability to access transportation or the quality of that transportation.

Table 4.5: Frequency of Client Complaints about Lack of Transportation

\begin{tabular}{l|r}
\hline $\begin{array}{l}\text { Complain about lack of } \\
\text { transportation }\end{array}$ & \multicolumn{1}{|l}{ Count } \\
\hline Frequently & 9 \\
\hline Sometimes & 4 \\
\hline Rarely & 2 \\
\hline I don't know & 0 \\
\hline Total Respondents & $\mathbf{1 5}$ \\
\hline
\end{tabular}

In Table 4.6, the 15 food pantry/meal provider respondents shared how often they think their clients visit food pantries or meal providers. Nine out of the 15 respondents (60\%) reported that clients frequently visit food pantries or meal providers. 
Table 4.6: Frequency of Clients Visiting Food Pantries or Meal Providers

\begin{tabular}{l|r}
\hline $\begin{array}{l}\text { Visit Food Pantry/ Meal } \\
\text { Provider }\end{array}$ & \multicolumn{1}{l}{ Count } \\
\hline Frequently & 9 \\
\hline Sometimes & 3 \\
\hline Rarely & 3 \\
\hline I don't know & 0 \\
\hline Total Respondents & $\mathbf{1 5}$ \\
\hline
\end{tabular}




\subsection{RESULTS OF FOOD ACCESS SPATIAL ANALYSIS}

\subsection{SPATIAL ANALYSIS METHODOLOGY}

To understand at a regional level the current state of transportation access for the food insecure, a spatial analysis of the service area's transit system was performed. Transit was chosen as the focus because it is the most cost-effective mode of transportation available.

Recent spatial data of local bus routes were gathered from the three transit agencies in the threecounty service area:

1. Hillsborough Area Regional Transit Authority (HART)

2. Pinellas Suncoast Transit Authority (PSTA)

3. Pasco County Public Transportation (PCPT)

For the purposes of this spatial analysis a three-quarter-mile buffer was used since a threequarter-mile walk to a bus stop is considered a reasonable distance to access transit. It is recognized as the distance a healthy person is willing or physically able to walk. Individuals with disabilities qualify for paratransit service within the three-county service area, and the service is offered within a three-quarter-mile radius of all local bus routes.

Data gathered by Feeding America in 2014 were used to determine the number of food insecure in the three-county service area. These data are collected through a national effort to survey food-insecure populations every four years (map.feedingamerica.org). The data are available at the census track level. Figure 1.1 depicts the local bus network, three-quarter-mile buffer, and the census tracts within the three-county service area.

To determine the number of food insecure with access to transit, the three-quarter-mile buffer was intersected with the census tracts. Area (square miles) was used as a proxy for population distribution within each census tract. For example, if 33\% of the area of a census tract intersected within the buffer, 33\% of the total number of food insecure within that census tract was assumed to have access to transit.

\subsection{SPATIAL ANALYSIS RESULTS}

Nationally, a highly affordable transportation option for households is public transit. In Tampa Bay, this most often means bus service. However, as is evident in the map below (Figure 5.1), bus routes run in limited areas of Tampa Bay. This leaves portions of the region with inadequate access to transit. 


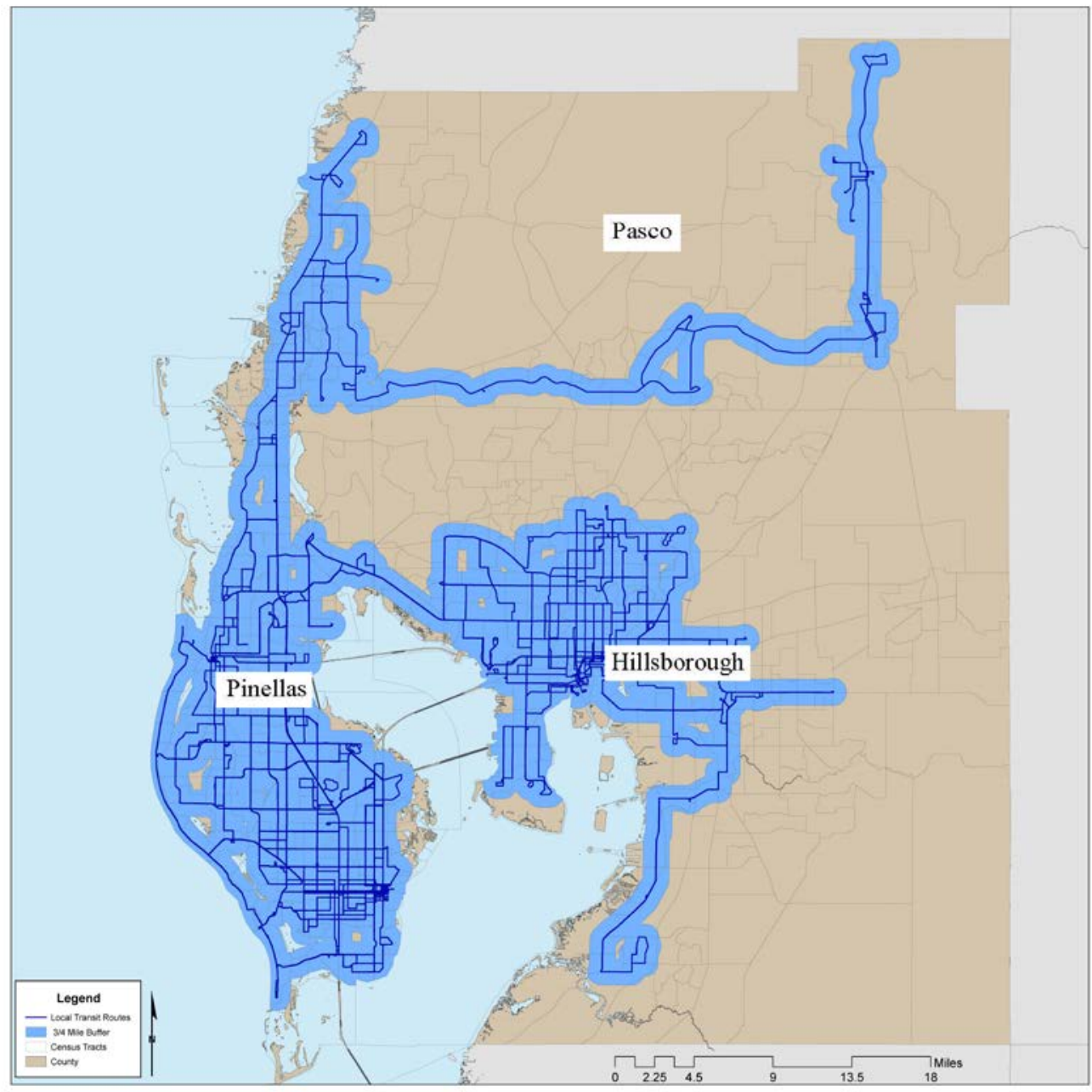

Figure 5.1: Local Transit Routes and Three-quarter-mile Buffer Area

The aggregated results of the spatial analysis by county are displayed in Table 5.1 below.

Table 5.1: 2014 Transit Access and Food Insecure in Tampa Bay

\begin{tabular}{l|r|r|r|r|r}
\hline \multirow{2}{*}{ County } & \multicolumn{2}{|l|}{$\begin{array}{l}\text { Food Insecure with } \\
\text { Transit Access }\end{array}$} & \multicolumn{2}{l|}{\begin{tabular}{l}
\multicolumn{2}{l}{ Food Insecure with } \\
Inadequate Access
\end{tabular}} & Total Food Insecure \\
\hline Hillsborough & 130,502 & $61 \%$ & 83,374 & $39 \%$ & 213,876 \\
\hline Pasco & 41,798 & $57 \%$ & 31,978 & $43 \%$ & 73,776 \\
\hline Pinellas & 128,801 & $86 \%$ & 21,049 & $14 \%$ & 149,850 \\
\hline Total & $\mathbf{3 0 1 , 1 0 1}$ & $\mathbf{6 9 \%}$ & $\mathbf{1 3 6 , 4 0 1}$ & $\mathbf{3 1 \%}$ & $\mathbf{4 3 7 , 5 0 2}$ \\
\hline
\end{tabular}


There are 136,401 people in Hillsborough, Pasco and Pinellas counties who are both food insecure and lack adequate access to transit.

Pasco County has the highest percentage of food insecure without access to transit at $43 \%$. Although the estimated percentage of Hillsborough County's food insecure residents without adequate transportation is only $4 \%$ less than that of Pasco County, the number of total food insecure in Hillsborough County is 2.6 times that of Pasco County due to population density. Regardless, both Hillsborough and Pasco counties have large rural areas in addition to suburban and urban areas.

Pinellas County has the lowest number of food insecure residents with inadequate access to transportation (14\%). Pinellas County is the densest county in Florida. Nearly all of Pinellas County's land area can be characterized as urban or suburban. As a result of this higher density, Pinellas County is able to support a bus route network that covers a large portion of its area and reach a large percentage of the food insecure. 


\subsection{RECOMMENDATIONS AND CONCLUSIONS}

The survey showed that transportation appears to be a frequent issue for food pantry and meal provider clients. However, most organizations surveyed have a bus stop within three-quarters of a mile, suggesting that the organizations, for the most part, have access to transit. The spatial analysis found that of the total 437,502 food-insecure individuals in Tampa Bay, 31\% do not have adequate access to transit. Based on the survey and spatial analysis, the following recommendations may improve transportation for the food insecure in Tampa Bay:

1. Although there is access to a bus stop at most of the organizations surveyed, transit should be made more efficient and straight-forward for food pantry/meal provider clients. Transit is the most cost-effective mode of transportation in Tampa Bay, as it is low cost and allows the user to make several miles-long trips, so it is a logical place to start when addressing the transportation needs of the food insecure. To improve transit, a further analysis should be undertaken to determine where the highest concentrations of food insecure without adequate access to transit are located. Emergency-food community stakeholders should partner with HART, PSTA and PCPT to identify strategies to increase access to food pantry and meal provider sites and grocery stores. As part of this collaboration, organizations should ensure their clients are aware of services they may qualify for, such as paratransit or other services for the transportation-disadvantaged.

2. Community stakeholders should explore multiple low-cost transportation-improvement strategies to bridge food access gaps. One potential strategy is leveraging vehicles owned by faith-based organization and organizations whose missions include serving the food insecure. These organizations may donate the use of a vehicle and a volunteer driver to transport foodinsecure people to food pantries, meal providers or grocery stores. A second strategy is bus-pass programs that distribute free or reduced-cost bus passes to clients. For instance, transit agencies typically sell passes in bulk to organizations. A third strategy is private partnerships with retail outlets. For example, grocery stores that stand to benefit from additional customers may schedule a free or affordable shuttle pick-up to bring food-insecure customers lacking transportation to their store. One example of a strategy already in action in Tampa Bay is Neighborly Care. This program provides seniors transportation to their congregate dining locations. As part of the trip they stop at a food pantry so that their clients may bring home additional groceries after their meal.

\section{Establish an organizational infrastructure dedicated to transportation for the food insecure that is initially a network of TBNTEH, transit authorities and the community stakeholders who filled out the survey. This network can lead to new relationships, funding, and pilot projects to help the food insecure in Tampa Bay access food.}

Although the recommendations resulting from this study focus on transportation barriers for the food insecure in the Tampa Bay region, they may have broader applicability for communities across America, particularly in rural areas where food insecurity may be even more prevalent. 
Bringing together a diverse group of stakeholders including: healthcare providers, faith based organizations, food pantry staff and food providers can lead to a better understanding of the transportation needs of the food insecure, and the availability of existing transportation resources. Identified gaps in the transportation network can be useful information for local transportation decision makers and providers to inform them of the specialized needs of this market and influence decisions that may result in solutions to reduce transportation barriers faced by the food insecure. 


\subsection{REFERENCES}

"Map The Meal Gap 2016 Highlights of Findings for Overall and Child Food Insecurity: A Report on County and Congressional District Food Insecurity and County Food Cost in the United States in 2014." Chicago, Illinois. 2015

N. Weinfield, G. Mills, C. Borger, M. Gearing, T. Macaluso, J. Montaquila, S. Zedlewski. "Hunger in America 2014 National Report Prepared for Feeding America." Chicago, Illinois. August 2014

S. Treuhaft, A. Karpyn, "The Grocery Gap: Who Hase Access to Healthy Food and Why it Matters." Oakland, CA 2010

H. Seligman, B. Laraia, \& A. Kushel.. Food Insecurity Is Associated with Chronic Disease among Low-Income NHANES Participants. Journal of Nutrition, 140, 304-310. 2009

H. Seligman, A. Bolger, D. Guzman, A. Lopez, \& K. Bibbins-Domingo. "Exhaustion of Food Budgets At Month’s End and Hospital Admissions for Hypoglycemia. Health Affairs.” 33(1): 116-123. 2014

C. Heflin., K. Siefert, \& D. Williams. "Food Insufficiency and Women’s Mental Health: Findings from a 3-year Panel of Welfare Recipients.” Social Science \& Medicine, 61, 1971-1982. 2005

R. Whitaker, S. Phillips, \& S. Orzol. "Food insecurity and the risks of depression and anxiety in mothers and behavior problems in their pre-school-aged children. Pediatrics.” 118, e859-e868. 2006

C. Gundersen, B. Kreider, \& J. Pepper. “The Economics of Food Insecurity in the United States.” Applied Economic Perspectives and Policy, 33(3), 281303. 2011. 


\section{APPENDIX}

COMMUNITY STAKEHOLDER SURVEY FORM 


\section{Tampa Bay Network to End Hunger}

Food Access Questionnaire

Organization Name:

Date:

Name (optional)

Contact information

(optional):

1. What is your organization type? Meal provider
Food Pantry
Other Food-related (please specify)
Meal Provider
Transportation-related (please specify)

Ministry

Other (please

specify)

2. What is your position or role at the organization?
Volunteer
Board Member
Executive Leader
Other (please specify)
Student

3. What is your interest in the Tampa Bay Network to End Hunger regarding transportation issues?

\section{The remaining questions are for those associated with food pantries and meal providers.}

4. What modes of transportation are you aware your clients use to access food pantry or meal provider organization? Please check all that apply.

\begin{tabular}{|c|c|}
\hline Personal Automobile & Family or Friend \\
\hline Taxi & Bicycle \\
\hline Rideshare (Uber/Lyft) & Other \\
\hline
\end{tabular}

5. How far is the closest bus stop to your food pantry or meal provider organization?
Less than $1 \frac{1}{2}$ mile
Unsure
$\square \quad$ Right in front
$\square$ Less than $1 / 4$ mile
$\square$ More than $1 \frac{1}{2}$ mile
Less than $3 / 4$ of a mile
There isn't a nearby bus stop

6. How often do you your clients complain about their lack of transportation to your food pantry or meal provider organization?
Sometimes
Rarely 

$\square$ Frequently
$\square$ I don't know

7. On average how often do your clients go to your food pantry or meal provider organization?

$\begin{array}{ll}\square & \text { Frequently } \\ \square & \text { Sometimes } \\ \square & \text { Rarely } \\ \square & \text { I don't know }\end{array}$

8. What are the days and hours of operation for your site (for food pantries and meal providers)?

\section{Thank you for your participation in this questionnaire!}


Transportation Research and Education Center

Portland State University

1900 S.W. Fourth Ave., Suite 175

Portland, OR 97201 